Revista Brasil. Bot., V.31, n.2, p.317-321, abr.-jun. 2008

\title{
Reproductive biology of the herkogamous vine Chiococca alba (L.) Hitchc. (Rubiaceae) in the Atlantic Rain Forest, SE Brazil
}

\author{
CIBELE CARDOSO DE CASTRO ${ }^{1,3}$, PAULO EUGÊNIO ALVES MACEDO DE OLIVEIRA ${ }^{2}$ and \\ REJANE MAGALHÃES DE MENDONÇA PIMENTEL ${ }^{1}$
}

(received: March 17, 2005; accepted: May 21, 2008)

\begin{abstract}
Reproductive biology of the herkogamous vine Chiococca alba (L.) Hitchc. (Rubiaceae) in the Atlantic Rain Forest, SE Brazil). The family Rubiaceae comprises a wide spectrum of floral mechanisms and two of them seem to be common in certain groups, e.g., distyly in Rubioidae and styllar pollen in Ixoroidae. These mechanisms include herkogamy, which is interpreted as a strategy that avoids self-pollination. This is the first report on the reproductive biology of Chiococca $a l b a$, a species that is widely distributed in America. We studied floral biology and the mating system, which were evaluated through fruit set comparisons after controlled crosses (self- and cross-pollinations and test for apomixis), as well as through the evaluation of pollen tube growth resulting from these controlled crosses. Flowers of C. alba are herkogamous, cream, protandrous and lasted for two days. No measurable nectar was found, despite the presence of a nectary-like structure at the base of the corolla tube. Chiococca alba is a preferentially self-incompatible species, but self-pollination and apomixis also contribute to the natural fruit-set. Its reproductive strategy (herkogamy associated with protandry) is different from that expected for members of Chiococceae tribe (i.e., styllar pollen presentation).
\end{abstract}

Key words - Atlantic Rain Forest, breeding system, Chiococca, floral biology, herkogamy, pollination, Rubiaceae

RESUMO - (Biologia reprodutiva da espécie hercogâmica Chiococca alba (L.) Hitchc. (Rubiaceae) na Floresta Tropical Atlântica, SE Brasil). A família Rubiaceae apresenta uma grande variedade de mecanismos florais e dois deles parecem ser comuns em determinados grupos, tais como a distilia em Rubioidae e apresentação de pólen no estilete em Ixoroidae. Estes mecanismos incluem a hercogamia, uma estratégia que parece minimizar as chances de autopolinização. Este é o primeiro estudo acerca da biologia reprodutiva de Chiococca alba, uma espécie de ampla distribuição na América. Foram coletados dados da biologia floral e do sistema reprodutivo, avaliado através da observação de formação de frutos e crescimento de tubos polínicos após cruzamentos controlados. Flores de $C$. alba são hercogâmicas, protândricas, de cor clara e duram dois dias. Não foi observada a produção mensurável de néctar, apesar da presença de uma estrutura semelhante a um disco nectarífero na base do tubo da corola. $C$. alba é uma espécie preferencialmente auto-incompatível, no entanto, a autopolinização e a apomixia também contribuem para a produção de frutos em condições naturais. A estratégia reprodutiva observada (protandria e hercogamia) é diferente daquela esperada para a tribo Chiococceae (i.e., apresentação de pólen no estilete).

Palavras-chave - Biologia floral, Chiococca, Floresta Atlântica, hercogamia, Rubiaceae, sistema reprodutivo

\section{Introduction}

The family Rubiaceae shows a wide spectrum of floral mechanisms characterized by different types of gynoecium and androecium organization. Despite this diversity, Robbrecht (1988) pointed out the presence of three reproductive strategies common in Rubiaceae, which are related to certain groups within the family. Distyly, morphologically characterized by the presence of two inter-compatible floral morphs, is generally

\footnotetext{
1. Universidade Federal Rural de Pernambuco, Departamento de Biologia, Área de Botânica, Av. Dom Manoel de Medeiros, s/n, 52171-900 Recife, PE, Brazil.

2. Universidade Federal de Uberlândia, Instituto de Biociências, Rua Duque de Caxias, 285, Caixa Postal 593, 38400-902 Uberlândia, MG, Brazil.

3. Corresponding author: cibelecastro@ hotmail.com
}

observed in species of Rubioidae (Barrett 1992 and references therein); styllar pollen presentation, which includes protandry and pollen presentation in the style, is generally recorded in Ixoroidae (Nilsson et al. 1990, De Block \& Igersheim 2001), whereas unisexual flowers seem to be almost restricted to Theligoneae and Anthospermae (Robbrecht 1988). Furthermore, other groups may present both distyly and styllar pollen presentation, or even reproductive traits apparently derived from them (e.g. Cinchoneae, Robbrecht 1988, Castro \& Oliveira 2001).

Both distyly and styllar pollen presentation include herkogamy, or the spatial separation between anthers and stigma of hermaphrodite flowers. In distyly this separation is observed early in the bud stage (Faivre 2000), whereas in styllar pollen presentation it is a result of style elongation after anther dehiscence (Imbert \& 
Richards 1993, Ladd 1994). Herkogamous species may be homomorphic or heteromorphic, depending on the number of floral types that are produced. Moreover, homomorphic herkogamy may be ordered (when floral morphology "controls" the orientation of pollinators) or unordered (Webb \& Lloyd 1986). In general, herkogamy is interpreted as a mechanism that avoids self-pollination and the mutual interference between sexual functions, i.e., pollen dispatch and receipt (Webb \& Lloyd 1986).

Apart from being commonly observed in Ixoreae, styllar pollen presentation is also thought to be the main reproductive strategy (Robbrecht 1988) of the monophyletic tribe Chiococceae of the Cinchonoidae (sensu Bremer 1996). Chiococca alba (L.) Hitchc., one of the approximately 40 species of the genus, is a vine that is widely distributed along North, Central and South America (Andersson 1992), and no data is available on its reproductive biology. The aim of this study is to describe the reproductive biology of this species from the Atlantic Rain Coastal Forest in southeastern Brazil, considering the reproductive tendency suggested by Robbrecht (1988) for the tribe.

\section{Material and methods}

We analyzed a population of Chiococca alba occurring naturally in the Parque Estadual da Serra do Mar, Núcleo Picinguaba (with 315,390 ha), southeastern Brazil (44⒋' $44^{\circ} 52^{\prime} \mathrm{W}$ and $23^{\circ} 20^{\prime}-23^{\circ} 22^{\prime} \mathrm{S}$ ), in a coastal plain area of the Atlantic Rain Forest. The climate is tropical wet (sensu Walsh 1996) with rain occurring every month.

Flowering phenological data were collected from 20 individuals during one year, from February 1999 to February 2000, following Fournier (1974). Floral traits such as period of anthesis, longevity, stigma receptivity (tested with the peroxidase technique, Kearns \& Inouye 1993) and presence of regions of odor production (using a neutral red solution, Dafni 1992) were observed daily through the monitoring of 10 tagged flowers from seven individuals.

Nectar secretion was evaluated on flowers (bagged in bud phase) with glass capillaries in four time intervals: early and late morning, midday, afternoon and night (until 20:00 h). For each interval a minimum of three individuals and five flowers per individual were used. The presence of ants was checked during flower manipulations, and no ants were observed collecting nectar from flowers.

The mating system was evaluated through fruit set comparisons in the field (using Chi-square tests, $\alpha=5 \%$, Sokal \& Rohlf 1981) after controlled crosses (self- and crosspollination), test for apomixis and natural pollination (control; see sample sizes in table 1), as well as through the evaluation of pollen tube growth resulting from these controlled crosses. For field experiments, inflorescences containing unopened flowers were enclosed in mash bags, hand pollinations were made in periods of stigma receptivity, and fruit development was followed until their total maturation.

Table 1. Results of reproductive experiments on Chiococca alba in the Atlantic Rain Forest, SE Brazil ( $n=$ total number of flowers tested).

\begin{tabular}{lc}
\hline Experiment & \% of Fruits $(n)$ \\
\hline Self-pollination & $12.50(40)$ \\
Cross-pollination & $61.54(39)$ \\
Apomixis & $5.55(36)$ \\
Control & $53.50(43)$ \\
\hline
\end{tabular}

Flowers used in cross-pollination experiments were emasculated immediately before the deposition of the pollen onto the stigma to prevent self-pollination; they were not emasculated in bud stage because they are too small and it would be possible to damage the stigma. Self-pollinated flowers received their own pollen, apomixis was evaluated through the emasculation of pre-anthesis buds, and open pollination was tested in marked inflorescences of nontreated individuals.

For controlled crosses $c a$. thirty marked individuals were used; for each treatment a minimum of 36 flowers from three to five individuals were used; each individual was used for more than one type of treatment. The observation of the pollen tubes resulting from hand pollinations was done using the fluorescence technique (modified from Martin 1959) in pistils fixed 12, 24, 48 and 72 hours after controlled crosses.

Voucher specimens of the plant species were deposited at the Universidade Estadual de Campinas herbarium (UEC 118309-118315).

\section{Results}

Flowering of Chiococca alba occurred massively in February (middle of the wet season), being highly synchronous between and within individuals (figure 1); fruits were completely matured in March. The axillary, verticillate inflorescences (figure 2) bear pentamerous, tubular, pendant flowers with a yellowish corolla and a green synsepalous calyx (figure 2-3). Floral scents were observed to be emitted especially by the corolla lobes. The gynoecium includes a bilobate, exerted stigma (figure 2) with a large receptive area (figure 4), a narrow style and an inferior, biloculate ovary, which bears two ovules. The five stamens are positioned below the stigma, inserted in the corolla tube (figure 3 ), and produce large amounts of powdery pollen. The species has only one floral morph. 


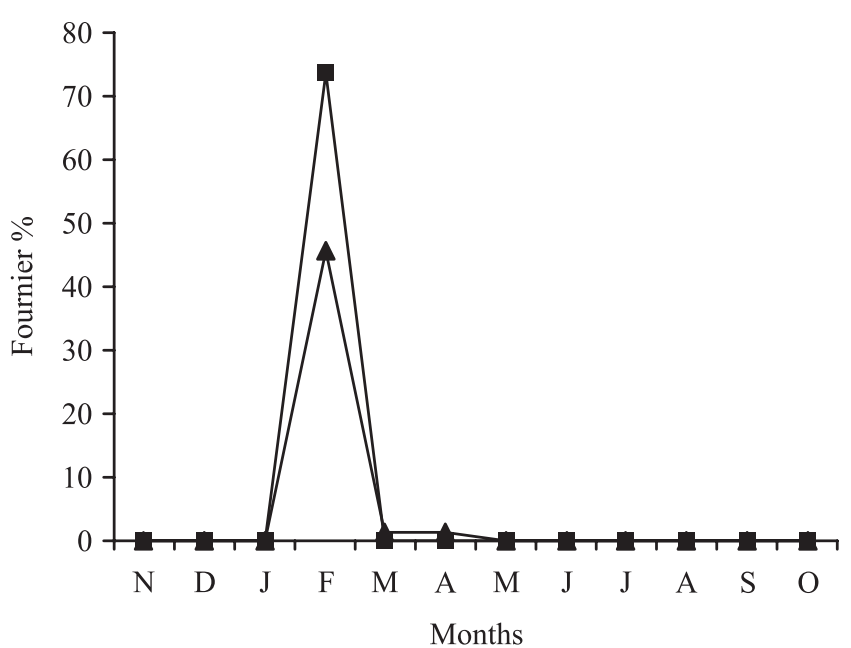

Figure 1. Fournier percentage of buds (triangles) and flowers (squares) of Chiococca alba in an area of Atlantic Rain Forest, SE Brazil.

Flowers opened in the afternoon and wilted after approximately 48 hours. The large receptive area of the stigma was active during all the floral lifespan, and the pollen was released at the pre-anthesis stage; by the morning of the day after the anthesis, all pollen had usually been removed. No nectar production was recorded; however, a nectary-like structure was observed above the ovary, similarly to the majority of Rubiaceae species.

Chiococca alba presented greater fruit set after cross pollination than after self-pollination $\left(\chi^{2}=14.40\right.$, $P<0.05$, table 1), and an ISI (sensu Bullock 1985) of 0.20 , being considered preferentially self-incompatible, although some fruit were formed after apomixis and selfpollination experiments. Fruit set after natural pollination (control) was as high as that after cross-pollination $\left(\chi^{2}=0.23, P>0.05\right.$, table 1$)$. The majority of self pollen tubes stopped growing in the stigma, and compatible ones took approximately 12 hours to reach the base of the style (figure 4). It was not possible to observe the tubes reaching the ovary because the tissue became dark during the bleaching with $\mathrm{NaOH}$.

\section{Discussion}

The flowering phenology strategy of Chiococca alba was massive (sensu Gentry 1974), with flowers being produced annually in large quantities during a short period (sensu Newstrom et al. 1994), resulting in a marked flowering synchrony within and between individuals.

Chiococca alba presented homomorphic, ordered herkogamy, because individuals bear only one floral type,
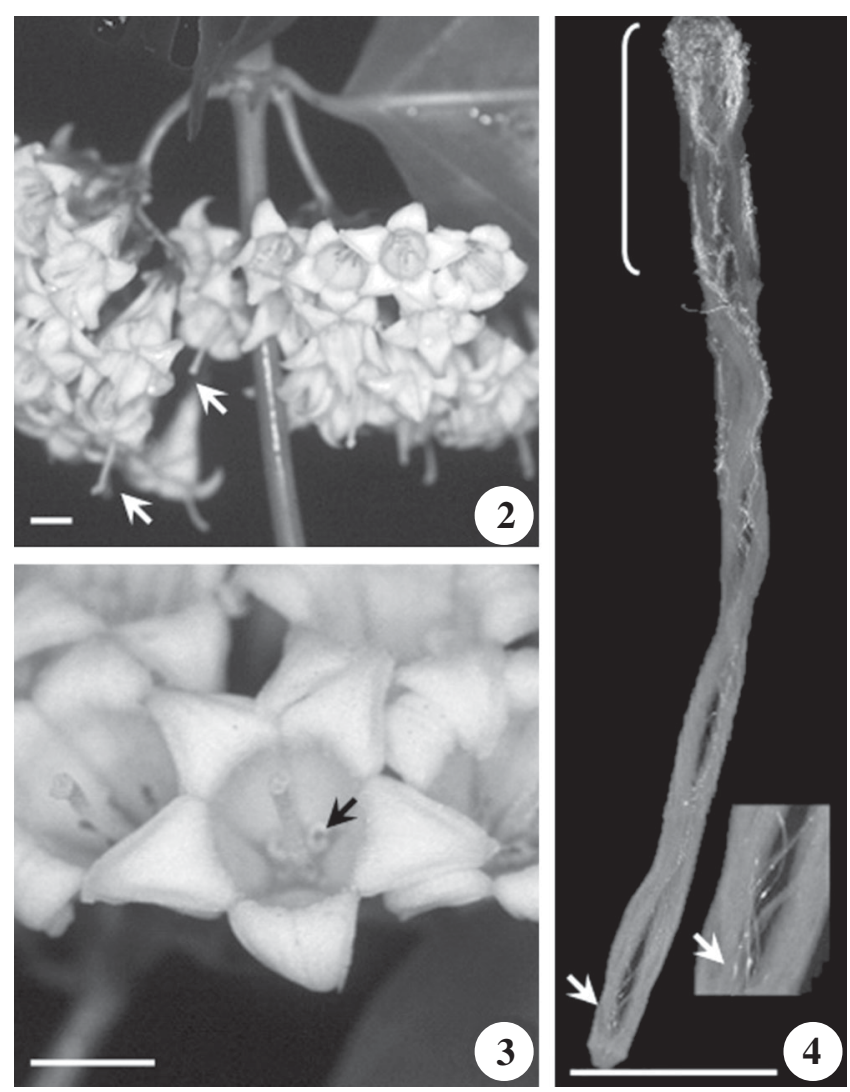

Figures 2-4. Reproductive features of Chiococca alba in an area of Atlantic Rain Forest, SE Brazil. 2. Axillary verticillate inflorescences; note the exerted stigma (arrow). 3. Flowers; note the inserted stamens (arrow). 4. Compatible pollen tubes (arrows) reaching the base of the style 12 hours after cross pollination; note the large stigma (white line). Bar $=0.32 \mathrm{~cm}$ (2), $0.30 \mathrm{~cm} \mathrm{(3),} 0.28 \mathrm{~cm}$ (4) and $0.13 \mathrm{~cm}$ (detail of figure 4).

that is hermaphrodite and tubular (Webb \& Lloyd 1986). Tubular flowers control the orientation of visitors' mouthparts, which are introduced in the bottom of the corolla to reach the nectar, generally produced and accumulated at the base of the floral tube (Webb \& Lloyd 1986).

Several factors may contribute to the reproductive success of this species. The high pollen production and the low number of ovules to be fertilized probably maximize the pollen flow. Moreover, the large receptive area of the stigma and its exerted position, which makes it easier to contact the pollinators' body, favors the pollen reception. Finally, the relative position of male and female organs also contribute to enhance outcrossing rates, because it may reduce interferences between male and female functions, a general problem of the architecture of hermaphrodite flowers, and a selective pressure influencing diverse floral features (Webb \& Lloyd 1986). 
The herkogamy observed in $C$. alba, the pendant position of flowers and their powdery pollen are conflicting features, because self-pollen may drop onto the stigma by gravity or wind (when many grains may also be lost), or during the pre-anthesis stage, germinating when the stigma becomes receptive. Moreover, the highly synchronized flowering minimizes the movement among plants, and may increase the chances of geitonogamy. Thus, fruit set after self-pollination is not insignificant in this species, and may contribute, together with apomixis and cross-pollination, to the total fruit set naturally obtained (control).

Chiococca alba flowers presented anther dehiscence in pre-anthesis buds, a feature typically found in species with secondary pollen presentation, a floral mechanism commonly recorded in members of the tribe Chiococceae (Robbrecht 1988). However, this is not the case of C. alba, whose pollen is presented by the anther. On the other hand, herkogamous, preferentially self-incompatible flowers, such as those of $C$. alba, are common in distylous species (Barrett 1992). The genus Chiococca has some related genera (sensu Bremer 1996) showing either distyly, as Hamelia (Bawa \& Beach 1983), or secondary pollen presentation, as Cephalanthus (Imbert \& Richards 1993).

The occurrence of monomorphy, i.e., the presence of only one floral morph in populations of typically distylous groups, is common in many genera of Rubiaceae and is interpreted as a derived character state (Hamilton 1990 and references therein). Chiococca alba has only pinlike flowers and produce fruits preferentially by crosspollination; in fact, some degree of self-compatibility is often recorded in monomorphic populations (Sobrevilla et al. 1983). Herbarium material from three other SE Brazilian States bear flowers morphologically similar to those described here, indicating that $C$. alba is a truly monomorphic species. The occurrence of monomorphy in groups of typically distylous genera was also recorded in other Rubiaceae species, such as Manettia cordifolia (Consolaro et al. 2005).

The incompatibility mechanism observed in C. alba showed some features also registered in other studies with Rubiaceae species. The pollen tube behaviour, i.e., the incompatibility site at the stigma in the great majority of the pistils observed, as well as the rapid growth of compatible ones, is similar to what is generally observed in distylous (Barrett 1992, Castro \& Araujo 2004, Castro et al. 2004) and protandrous (Castro \& Oliveira 2001) species of Rubiaceae.

The reproductive trends observed among Rubiaceae tribes, as suggested by Robbrecht (1988), are important because they provide useful and interesting insights on the taxonomic and reproductive aspects of these plants, nevertheless they must be carefully considered. Distyly and secondary pollen presentation are strategies more commonly found in some tribes, but many exceptions may be found. Interestingly, almost all exceptions include only some features of these expected strategies, or even intermediate features probably derived from them. Ferdinandusa speciosa (Castro \& Oliveira 2001) shows protandry, whereas its subtribe, Cinchoninae, includes distyly or secondary pollen presentation; Guettarda scabra (Richards \& Koptur 1993), Hamelia patens (Imbert \& Richards 1993) and Posoqueria spp. may present both secondary pollen and distyly, whereas their tribe (Gardenieae) shows exclusively the first strategy (Bawa et al. 1985). Data presented here for C. alba represent another case showing the trends as suggested by Robbrecht (1988) have limited predictive power.

Acknowledgements - To M. Sazima (Universidade Estadual de Campinas) for critical reading the manuscript, I. Bressan (Universidade Estadual de Campinas) for technical support, Depto. Botânica (Universidade Estadual de Campinas) for logistic support and E. Rosa for help in field work. This study is part of the $\mathrm{PhD}$ thesis of the first author (Universidade Estadual de Campinas, CNPq grant 141402/1997-0).

\section{References}

ANDERSSON, L. 1992. A provisional checklist of Neotropical Rubiaceae. Scripta Botanica Belgica 1:1-199.

BARRETT, S.C. 1992. Heterostylous genetic polymorphisms: model systems for evolutionary analysis. In: Evolution and function of heterostyly (S. C. H. Barrett, ed). Springer-Verlag, Berlin, p.1-29.

BAWA, K.S. \& BEACH, J.H. 1983. Self-incompatibility systems in the Rubiaceae of a tropical lowland wet forest. American Journal of Botany 70:1281-1288.

BAWA, K.S., BULLOCK, S.H., PERRY, D.R., COVILLE, R.E. \& GRAYUM, M.H. 1985. Reproductive biology of tropical lowland rain forest trees. II. Pollination systems. American Journal of Botany 72:346-356.

BREMER, B. 1996. Combined and separate analyses of morphological and molecular data in the plant family Rubiaceae. Cladistics 12:21-40.

BULLOCK, S.H. 1985. Breeding systems in the flora of a tropical deciduous forest. Biotropica 17:287-301.

CASTRO, C.C. \& ARAUJO, A.C. 2004. Distyly and sequential pollinators of Psychotria nuda (Cham. and Schelet.) Wawra (Rubiaceae) in the Atlantic Forest, SE Brazil. Plant Systematics and Evolution 244:131-139.

CASTRO, C.C. \& OLIVEIRA, P.E.A.M. 2001. Reproductive biology of the protandrous Ferdinandusa speciosa Pohl. (Rubiaceae) in SE Brazil. Revista Brasileira de Botânica 24:167-172. 
CASTRO, C.C., OLIVEIRA, P.E.A.M. \& ALVES, M.C. 2004. Breeding system and floral morphometry of distylous Psychotria L. species in the Atlantic Rain Forest, SE Brazil. Plant Biology 755-760.

CONSOLARO, H.S., BENTO, H. \& OLIVEIRA, P.E. 2005. Variação floral e biologia reprodutiva de Manettia cordifolia Mart. (Rubiaceae). Revista Brasileira de Botânica 28:85-94.

DAFNI, A. 1992. Pollination ecology - a practical approach. Oxford University Press, Oxford.

DE BLOCK, P. \& IGERSHEIM, A. 2001. Stigma of the African genera Rutidea and Nichallea (RubiaceaeIxoroideae-Pavetteae): highly modified receptive surfaces. International Journal of Plant Sciences 162:567-578.

FAIVRE, A.E. 2000. Ontogenetic differences in heterostylous plants and implications for development from a herkogamous ancestor. Evolution 54:847-858

FOURNIER, L.A. 1974. Un método cuantitativo para la medición de características fenológicas en árboles. Turrialba 24:422-423.

GENTRY, A.H. 1974. Coevolutionary patterns in Central American Bignoniaceae. Annals of the Missouri Botanical Garden 61:728-759.

HAMILTON, C.W. 1990. Variations on a distylous theme in a Mesoamerican Psychotria subgenus Psychotria (Rubiaceae). Memoirs of the New York Botanical Garden 55:62-75.

IMBERT, F.M. \& RICHARDS, J.H. 1993. Protandry, incompatibility, and secondary pollen presentation in Cephalanthus occidentalis (Rubiaceae). American Journal of Botany 80:395-404.

KEARNS, C.A. \& INOUYE, D.W. 1993. Techniques for pollination biologists. University Press of Colorado, Niwot.
LADD, P.G. 1994. Pollen presenters in the flowering plants - form and function. Botanical Journal of the Linnean Society 115:165-175.

MARTIN, F.N. 1959. Staining and observing pollen tubes in the style by means of fluorescence. Stain technology 34:125-128.

NEWSTROM, L.E., FRANKIE, G.W. \& BAKER, H.G. 1994. A new classification for plant phenology based on flowering patterns in lowland tropical rain forest trees at La Selva, Costa Rica. Biotropica 26:141-159.

NILSSON, L.A., RABAKONANDRIANINA, E., PETTERSSON, B. \& RANAIVO, J. 1990. Ixoroid secondary pollen presentation and pollination by small moths in the Malagasy treelet Ixora platythyrsa (Rubiaceae). Plant Systematics and Evolution 170:161-175.

RICHARDS, J.H. \& KOPTUR, S. 1993. Floral variation and distyly in Guettarda scabra L. (Rubiaceae). American Journal of Botany 80:31-40.

ROBBRECHT, E. 1988. Tropical woody Rubiaceae. Opera Botanica Belgica 1:1-271.

SOBREVILLA, C., RAMIREZ, N. \& ENRECH, N.X. 1983. Reproductive biology of Palicourea fendleri and $P$. petiolaris (Rubiaceae), heterostylous shrubs of a tropical cloud forest in Venezuela. Biotropica 15:161-169.

SOKAL, R.R. \& ROHLF, J.R.F. 1981. Biometry. W. H. Freeman, San Francisco.

WALSH, R.P.D. 1996. The climate. In The tropical rain forest: an ecological study (P.W. Richards, ed.). Cambridge University Press, Cambridge, p.159-255.

WEBB, C.J. \& LLOYD, D.G. 1986. The avoidance of interference between the presentation of pollen and stigmas in Angiosperms. II. Herkogamy. New Zealand Journal of Botany 24:163-178. 